\title{
Corrigendum: Single cell electroporation for longitudinal imaging of synaptic structure and function in the adult mouse neocortex in vivo
}

\author{
Stéphane Pagès ${ }^{1+}$, Michele Cane ${ }^{1+}$, Jérôme Randall ${ }^{1}$, Luca Capello ${ }^{2}$ and \\ Anthony Holtmaat ${ }^{1 *}$ \\ 'Department of Basic Neurosciences and the Center for Neuroscience, Centre Médical Universitaire, Geneva, Switzerland, \\ ${ }^{2}$ Itopie Informatique, Société Coopérative, Geneva, Switzerland
}

Keywords: Single cell electroporation, in vivo, Long-term imaging, calcium imaging, dendritic spine

\section{OPEN ACCESS}

Edited and reviewed by:

Agustín González,

Universida Complutense de Madrid,

Spain

*Correspondence: Anthony Holtmaat, anthony.holtmaat@unige.ch

${ }^{t}$ These authors have contributed equally to this work.

Received: 13 April 2015 Accepted: 22 April 2015

Published: 12 May 2015

Citation:

Pagès S, Cane $M$, Randall $J$ Capello L and Holtmaat A (2015)

Corrigendum: Single cell electroporation for longitudinal imaging of synaptic structure and function in the adult mouse neocortex

in vivo. Front. Neuroanat. 9:56. doi: 10.3389/fnana.2015.00056

\section{A corrigendum on:}

Single cell electroporation for longitudinal imaging of synaptic structure and function in the adult mouse neocortex in vivo

by Pagès, S., Cane, M., Randall, J., Capello, L., and Holtmaat, A. (2015). Front. Neuroanat. 9:36. doi: 10.3389/fnana.2015.00036

\section{Acknowledgments}

This work was supported by the Swiss National Science Foundation (31003A_135631, grant to AH), the National Centre of Competence in Research (NCCR) SYNAPSY financed by the Swiss National Science Foundation (51AU40_125759), the International Foundation for Research on Paraplegia, and the Hans Wilsdorf Foundation.

Conflict of Interest Statement: The authors declare that the research was conducted in the absence of any commercial or financial relationships that could be construed as a potential conflict of interest.

Copyright $\odot 2015$ Pagès, Cane, Randall, Capello and Holtmaat. This is an open-access article distributed under the terms of the Creative Commons Attribution License (CC BY). The use, distribution or reproduction in other forums is permitted, provided the original author(s) or licensor are credited and that the original publication in this journal is cited, in accordance with accepted academic practice. No use, distribution or reproduction is permitted which does not comply with these terms. 